\title{
Redaktionel indledning
}

Dette nummer af Studier i Læreruddannelse og -Profession består af fem artikler inden for nummerets tema, differentiering, samt to artikler uden for tema.

Redaktionen har fundet det relevant at sætte fokus på differentiering, idet "differentiering i fag, skole og læreruddannelse gennem årtier har været anvendt som begreb til at begribe sorterings- og fordelingsprocesser samt til at sætte undervisningsmæssige forskelle i fagundervisningen, og (differentiering) kan henvise til et elevniveau, der som fænomen særligt var kendt, før undervisningsdifferentiering blev indført som et grundlæggende pædagogisk og didaktisk princip med indførelsen af enhedsskolen i 1993, og til undervisningsdifferentiering, der nødvendigvis må forstås som værende indlejret i sociale og faglige praksisser" (ordlyd fra call for papers til dette nummer). Vi har med nummeret ønsket at sætte fokus på differentiering i fag, skole og læreruddannelse og dermed ønsket at bidrage til at øge og kvalificere vores viden om differentiering set i relation til skolen, læreruddannelsen og de fag, der udspiller sig i disse kontekster.

At differentiere betyder at sætte en forskel, at adskille, at spalte, at nuancere og henviser som oftest til, at nogen differentierer noget eller nogle. Historisk betragtet er der en lang række differentieringsprocesser knyttet til skolen og til uddannelsesprocesser i almindelighed, hvor nogle af disse må antages at være uddannelsespolitisk, pædagogisk og didaktisk intentionelle og formodentligt velovervejede, og andre må snarere forstås som værende underliggende og ikkeintentionelle og må nødvendigvis forstås på et mere strukturelt niveau. Med andre ord har differentieringsprocesser i fag, skole og uddannelse altid fundet sted, men har gennem tiden antaget forskellige former og udtryk på baggrund af varierende samfundsmæssige og policyforankrede strømninger og fordringer og pædagogiske og almen- og fagdidaktiske udviklinger.

Nummeret indledes med en artikel af Stefan Ting Graf og Dorthe Carlsen med titlen "Om at måle lærernes differentieringspraksis". Med udgangspunkt i spørgsmålet om, hvorvidt læreres differentieringspraksis kan måles, præsenterer forfatterne fire teoretiske forståelser af begrebet undervisningsdifferentiering. Herefter præsenteres en analyse af en række kvantitative undersøgelser af læreres differentieringspraksis, og resultaterne af disse analyser peger på, at de undersøgte studier måler forskellige aspekter af 
fænomenet undervisningsdifferentiering. Forfatterne argumenterer for, at der ikke foreligger en bredt accepteret metode i forbindelse med kvantitative studier af undervisningsdifferentiering, og at der således er et forskningsmæssigt behov for en mere dækkende teoretisk og empirisk afklaring af begrebet undervisningsdifferentiering.

Raffaele Brahe-Orlandi bidrager med artiklen "Differentierede deltagelsesmuligheder i entreprenørskabsundervisning". Her undersøger han potentialer og udfordringer i de undervisningsformer, der iværksættes i entreprenørskabsundervisningen, når målet er at fremme mangfoldige deltagelsesmuligheder hos eleverne. Brahe-Orlandi åbner forståelsen af det læringslandskab, eleverne deltager i som pædagogisk entreprenørskab, og definerer med Wenger det gode undervisningsdesign som et design med så mange deltagelsesmuligheder som muligt, der kan tilbyde alle elever fristende deltagelsesidentiteter. En deltagelsesidentitet, der i denne forbindelse også er en entreprenant elev, defineret som initiativrig og drevet af indre motivation. Læringsforståelsen udvikles endvidere med Dewey, Hannah Arendt og Schaffers og Resnicks begreb om thick authenticity. Brahe-Orlandis undersøgelse knytter sig til en designintervention, der er gennemført i hans ph.d.-arbejde, og materialet for herværende undersøgelse er fokusgruppeinterviews med elever fra en 8. klasse, efter designet er blevet gennemført. Gennem analyse skaber han tre forskellige narrativer, der kredser om motivation, frihed og mening som autenticitet. Der gives hermed nogle meget billedskabende og stoflige billeder af, hvordan eleverne håndterer et læringsforløb med en meget større åbenhed end en mere klassisk faglig undervisning. Undervisningsformer, der kræver mange afbalanceringer, men som umiddelbart åbner for mangfoldige deltagelsesmuligheder. Og dermed med en mulighed for at bidrage til en grundskole for alle.

I artiklen "Når skolens børn evaluerer sig selv" sætter Lise Aagaard Kaas, Mathias Sune Berg og Sine Penthin Grumløse fokus på skolens selvevalueringspraksisser og de betydninger, disse har for skolens elever. Forfatterne peger indledningsvist på, at i takt med skolens diskurser om livslang læring ser vi i stigende grad, at børn skal vurdere, hvad de har lært; men ligeså knytter skolens fordringer om selvevaluering også til mere personlige og sociale forhold. Artiklen præsenterer og diskuterer eksempler på disse evalueringspraksisser samt deres betydning for børns deltagelsesmuligheder. Artiklen tager afsæt i et empirisk studie af børns hverdagsliv i skolen og selvevaluering som social praksis. I artiklen diskuteres ligeledes den udspændthed, som skolens lærere befinder sig i, mellem skolepolitiske fordringer om eva- 
luering på den ene side og den daglige evalueringspraksis, der bl.a. har til hensigt at udvikle undervisningen og styrke elevernes læring og trivsel, på den anden side. Forfatterne viser bl.a., at skolens individualiserede evalueringspraksisser rummer betydninger for elevernes muligheder for deltagelse samt oplevelser af mestring.

I artiklen "Køn og teknologi i folkeskolen" undersøger Pia Susanne Frederiksen, hvordan lærere og elevers kønskonstruktioner påvirker deres tilgang til teknologiforståelsesundervisning, og hvordan den didaktiske rammesætning arbejder ind i disse forhold. Spørgsmålene undersøges gennem et casestudie i en 2. klasse, der bliver undervist i forsøgsfaget teknologiforståelse. Mens den danske folkeskole traditionelt har erfaring med, at det er drengene, der bliver optagede af digitale teknologier og de computationelle processer, er både drenge og piger meget engagerede i det nye fag. Ved at inddrage motivationsforskning fra naturfagene kan Frederiksen skelne mellem drenges og pigers måde at engagere sig i faget på, og hun vurderer, at de fleste pigers engagement og interesse $i$ faget umiddelbart er mere skrøbeligt end de fleste drenges. I forlængelse af dette knytter de fleste pigers engagement i det faglige arbejde sig til en bredere, meningsfuld kontekst, mens de fleste drenge kan engagere sig i det tekniske i sig selv. Frederiksen - og nogle af de deltagende piger - observerer endvidere en kønnet arbejdsdeling i de fælles arbejdsprocesser. At pigerne i så høj grad engagerer sig i teknologifaget, binder Frederiksen sammen med den didaktiske rammesætning i undervisningen i casen, der er at ligne med motiverende undervisning i naturfagene. Der er tale om nogle designprincipper, hvor der er mulighed for at skabe mening i den faglige proces for den enkelte elev, og hvor der samtidig er rum for at præge det faglige arbejde i en samarbejdende læringskultur. Casen fra folkeskolens indskoling viser på denne måde et teknologifag, der kan engagere piger og drenge, men hvor der også er mange didaktiske og pædagogiske forhold i spil. Forhold, der ikke nødvendigvis peger i samme retning, og som sammenfletter sig videre gennem skoleforløbet som forhold, der giver drenge og piger mulighed for at udfolde sig fagligt med teknologi.

Med udgangspunkt i Deweys pædagogik diskuterer Christina Højlund i artiklen "Praksisnær undervisning - differentierede lærings- og deltagelsesmuligheder i undervisningen" elevers muligheder for at erfare den praktiske virkelighed. Med begrebet praksisfaglighed ønsker forfatteren at pege på en måde at forbinde og styrke sammenhængen mellem elevernes dannelse, deres faglige læring og det at åbne for flere livs- og uddannelsesperspektiver for den enkelte. Praksisfaglighed optræder derfor i artiklen som en måde at 
skabe flere differentierede veje til faglig læring gennem flere valg- og deltagelsesmuligheder og som en måde at genetablere en tydelig sammenhæng mellem skolens formål, fagene og elevens udvikling og dannelse til et autonomt og virksomt menneske, der bidrager til samfundet - både demokratisk og som arbejdskraft. I artiklen besvares spørgsmålet: "Hvordan forstås praksisnær undervisning, og hvilke muligheder for differentierede lærings- og deltagelsesmuligheder skabes med praksisnær undervisning?" på baggrund af empiri fra forskningsprojektet "Styrket inddragelse af den praksisnære og anvendelsesorienterede dimension i folkeskolen", og artiklen konklusioner peger i retning af at "en praksisnær undervisning, der baserer sig på Deweys forståelse af nødvendigheden af den formelle uddannelse, og som ser uddannelse som middel til at udvikle og forfine vores evne til at tænke og handle intelligent til samfundets bedste, vil åbne for flere livsmuligheder og -perspektiver for alle skolens elever". Endvidere viser forfatteren, at "differentierede deltagelsesmuligheder, som den praksisnære undervisning lægger op til, kan bidrage til, at flere børn og unge oplever skolen som et godt og trygt sted at være og som et sted, hvor der er plads til, at de kan udvikle sig med deres individuelle forskelligheder, behov og ønsker".

I dette nummer bringer vi desuden to artikler uden for nummerets tema. Den ene er en artikel om udvikling af undervisningen i faget engelsk og den anden en artikel om didaktiske intentioner i forbindelse med udeskole.

Benthe Fogh Jensen bearbejder i artiklen "Kvalitet i engelskundervisningen på mellemtrinet - et kritisk blik på indhold og metoder" erfaringerne fra et deltagerbaseret aktionsforskningsprojekt, der forsøgte at undersøge og udvikle et bud på et teoretisk og pædagogisk grundlag for undervisningen i engelsk på mellemtrinet. I projektet blev følgende spørgsmål: “Hvilke faktorer er af betydning for kvaliteten i engelskundervisningen og elevernes sprogtilegnelse på mellemtrinet i den danske grundskole?" samt "I hvor høj grad kan erhvervede indsigter om dette være medvirkende til en rekonceptualisering af gældende praksis i forhold til indhold og metoder i engelskundervisningen på mellemtrinet?" søgt besvaret. Centralt i artiklen står begrebet disconnects, der benyttes til at vise, hvor teoretisk viden ikke er reflekteret i didaktiske og pædagogiske valg i undervisningen. Artiklen afdækker nogle faktorer af betydning for kvaliteten i engelskundervisningen og elevernes sprogtilegnelse på mellemtrinet i den danske grundskole, underbygget af andre forskningsresultater på området, der peger på vigtigheden af interaktionsmønstre, der understøtter sproglige hypotesedannelser, en undervisning, der understøtter elevers sproglige progression 
samt vigtigheden af stilladsering af undervisningen på flere niveauer. De erhvervede indsigter peger på flere områder, hvor en rekonceptualisering af gældende praksis og metoder ville kunne kvalificere didaktiske designs til engelskundervisningen på mellemtrinnet.

Dorthe Vang Eggersens artikel “Ej, hvorfor skal vi ud?! Didaktisk intentionalitet i udeskole" afslutter dette nummer. Artiklen bidrager til at udvikle en vidensbaseret forståelse af udeskole, som det praktiseres i den danske folkeskole. Eggersen adskiller systematisk udeskole fra folkeskolereformens åbne skole. Selv om der er mange fællesnævnere pædagogisk og didaktisk for udeskole og åben skole, adskiller de sig også fra hinanden gennem forskellig oprindelse og forskellige udviklingsveje. Udeskole og åben skole bevæger sig begge ud af klasseværelset, men udeskole er ikke kun uden for klasseværelset, men også udenfor, som under åben himmel, og udeskole knytter sig til en friluftslivs- og naturfagsorientering, mens den åbne skole retter sig mod kulturliv og kreativitet.

Den didaktiske intentionalitet i udeskoleaktiviteter, som de går for sig i den danske folkeskole, undersøges empirisk gennem en lang række undervisningsforløb i udeskole, der er blevet udviklet gennem aktionsforskning i et større udviklingsprojekt. Forløbene undersøges i forhold til en teoretisk oparbejdet kategorisering, og det bliver vist, at den didaktiske intentionalitet i langt de fleste forløb retter sig mod 'sprog som ledsagelse til handling', der iværksættes for at skærpe elevernes fagsprog og faglige viden gennem konkretisering af et fagligt indhold. Intentionaliteten i en mindre række forløb retter sig mod motion og bevægelse i fag og mod stedbaseret læring. Udeskole praktiseres altså ikke kun med intention om undersøgende og omverdensrettede læreprocesser, og mens forløbene, der retter sig mod sprog som ledsagelse til handling, har en vidensbaseret baggrund, er den stedbaserede læring i mindre grad etableret, både i sin praksis og i sin vidensbase.

God læselyst fra redaktionen!

René B. Christiansen, Thomas Thyrring Engsig og Vibeke Schrøder 